\title{
Review on the start-up experiences of continuous fermentative hydrogen producing bioreactors
}

\section{A R T I C L E I N F O}

\section{Article history:}

Received 23 April 2014

Received in revised form

16 July 2014

Accepted 5 August 2014

\section{Keywords:}

Biohydrogen

Production

Continuous system

Bioreactor

Start-up

\begin{abstract}
A B S T R A C T
The start-up of continuous biohydrogen fermentations is a complex procedure and a key to acceptable hydrogen production performance and successful long-term operation. In this review article, the experiences gained and lessons learned from relevant literature studies dealing with various aspects of $\mathrm{H}_{2}$ producing bioreactor start-up are comprehensively surveyed. Firstly, the importance of $\mathrm{H}_{2}$-forming biosystem start-up including its main steps is outlined. Afterwards, the role of main influencing factors and methods (e.g. strain selection, seed pretreatment and inocula stimulation, switch-over time, bioreactor design, operating conditions) in avoiding the deterioration of starting a reactor is analyzed and presented in detail. Finally, the so far suggested applicable start-up strategies and the corresponding findings are critically discussed pointing out the advantages and disadvantages of each strategy.
\end{abstract}

(C) 2014 Published by Elsevier Ltd.

\section{Contents}

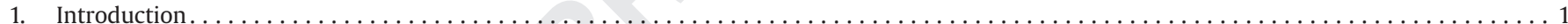

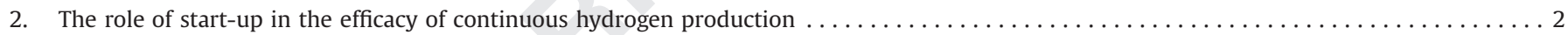

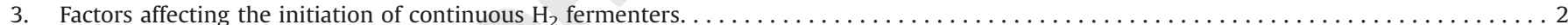

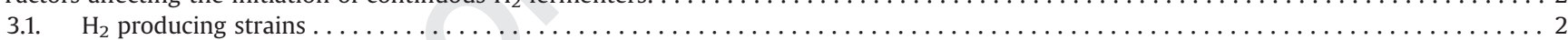

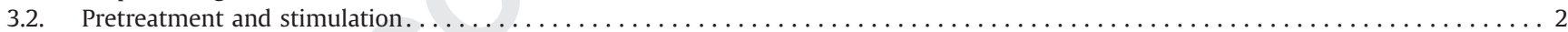

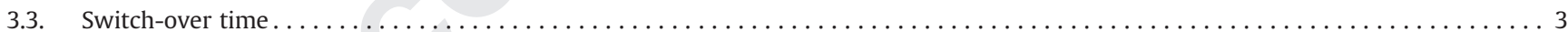

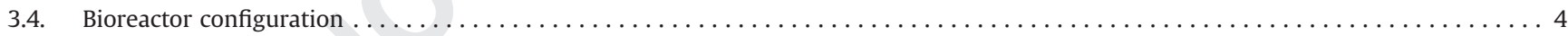

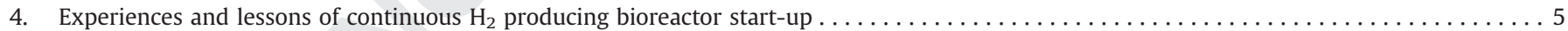

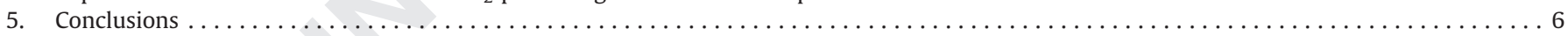

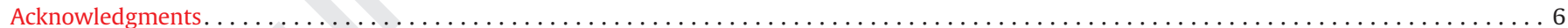

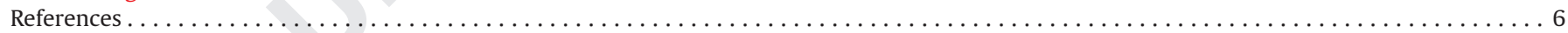

\section{Introduction}

Hydrogen is an emerging candidate among the various alternative energy carriers. $\mathrm{H}_{2}$ is believed to help the transition of current fossil-based economy to a renewable-based one [1], however, only if it is derived by sustainable processes. Though $\mathrm{H}_{2}$ can be prepared by many conventional and mature methods (e. g. steam reformation of hydrocarbons), environmental-friendly methods such as with biological routes are required and still subjects to extensive research [2].

\footnotetext{
* Corresponding author. Tel.: +36 88 624385; fax: +36 88624292

E-mail address: bakonyipeter85@gmail.com (P. Bakonyi).
}

Nowadays, microbiologically produced hydrogen is recognized as an emerging way ahead, especially when formed via dark fermentation because of its inherent advantages such as relatively low energy demand (attributed to the gentle reaction conditions), the usability of wide range of feedstocks e.g. derivates of biomass, waste streams and agricultural residues [3-5], and the possibility to integrate with other e.g. membrane-based processes in order to accomplish the sufficient reuse of hydrogen producing cells [6] or to upgrade $\mathrm{bioH}_{2}$ [7-9] so that it could be a viable feedstock in energy efficient fuel cells.

Nevertheless, additional efforts are still essential to make biohydrogen generation more attractive. From practical aspect, the two major criteria to be considered are $\mathrm{H}_{2}$ production yields and rates. As a result of the investigations in the past decades, several factors were identified that significantly affect the main 
technological indicators mentioned above. Among them, bioreactor configuration and operation are apparent ones [10]. Regardless the type of the fermenter, it can be concluded that feasible biohydrogen fermentation should be conducted in continuous rather than batch systems [11], e.g. due to higher expectable process efficiencies.

The establishment of continuous flow bioreactors usually starts in batch mode, and it is to note that successful transition and reliable, long-term operation is highly influenced by the start-up strategy applied [12-14]. However, up to the authors' best knowledge, there is no recent review paper comprehensively surveying start-up experiences in continuous hydrogen producing bioreactors. Hence, in this work, the experiences gained and lessons learned from batch to continuous shifts are reviewed and suggestions are given to achieve proper continuous operation.

\section{The role of start-up in the efficacy of continuous hydrogen production}

Process instability is a frequently observed drawback in fermentative $\mathrm{H}_{2}$ production [15] that could be attributed to multiple reasons as specified later in this paper. In fact, beyond steady-state operational parameters and medium composition, stable and continuous bioreactor operation to obtain acceptable hydrogen production performance is strongly dependent on the start-up phase [16]. It could involve the following steps:

- Selection of the hydrogen producing biocatalysts.

- Enhancement and acclimatization of $\mathrm{H}_{2}$-forming strains to fermentation circumstances.

- System transition until steady-state is reached.

These steps in a line require great attention and comprehensive control in terms of environmental and operational circumstances to develop robustful $\mathrm{H}_{2}$ fermenting culture [17]. Otherwise, starting a reactor may easily be deteriorated e.g. due to the insufficient growth and $\mathrm{H}_{2}$ production capacity of microorganisms. Such bottlenecks can be avoided or at least mitigated by properly designed start-up strategy.

In the next sections of the paper, the aforementioned parts of the continuous dark fermentative bioreactor establishment are outlined and discussed in details.

\section{Factors affecting the initiation of continuous $\mathrm{H}_{2}$ fermenters}

\section{1. $\mathrm{H}_{2}$ producing strains}

Fermentative biohydrogen generation can be realized either by pure cultures [18] such as Escherichia coli [19,20] or mixed bacterial consortia $[21,22]$ and both have their own benefits. For example, cultures of pure isolates may be easier to control but need constantly sterile environment to prevent contamination that is difficult and costly to maintain out of laboratories. Considering their application in a non-sterile environment, pure cultures may be used in the bioaugmentation of diverse $\mathrm{H}_{2}$ producing population to attain better gas turnouts [23]. The restrictions of sterility criteria are the main reasons why mixed bacterial communities are preferred to their pure counterparts in real-case, scaled-up applications.

\subsection{Pretreatment and stimulation}

Conceptually, anaerobic, mixed $\mathrm{H}_{2}$-producing consortia (e.g. in sewage sludge, biogas plants, etc.) are built up by co-existing and synergic species [24]. However, in most cases, they naturally occur together with $\mathrm{H}_{2}$-consumer microorganism such as methanogenic archaea, homoacetogenic (producing acetate from $\mathrm{CO}_{2}$ and $\mathrm{H}_{2}$ )-, lactic- and propionic acid bacteria which must certainly be suppressed or more preferentially totally eliminated [25]. As a consequence, regardless the source of mixed inocula, it should undergo initial pretreatment in order to select the desired whole cell biocatalysts. For such purposes, a lot of tools have been developed based on heat shock, addition of chemicals, swinging the oxidation-reduction potential (ORP) e.g. by aeration, high energy irradiation, alteration of $\mathrm{pH}$, freezing and thawing [2628]. These pretreatment techniques exploit the distinct sensitivity of strains present in the mixture and in general could provide a satisfactory starter culture to be used as seed inocula for subsequent biohydrogen fermentation. In other words, these procedures aim to eliminate hydrogen-consuming vegetative cells and on the other hand, are devoted to enhance acidogenic- and often sporulative $\mathrm{H}_{2}$-forming cells [29].

Although culture pretreatments can effectively suppress undesired microbiological activity, they may also reduce the number of indigenous $\mathrm{H}_{2}$-former bacteria, especially the ones with low stress tolerance. For these reasons, as a next step after culture pretreatment, treated inocula should be submitted to stimulative environment (e.g. to a batch reactor) to let the microbes proliferate so that a reasonable amount of active cellmass can be accumulated, harvested and further applied. Also, batch cultivation can play a role to help biofilm development on carrier materials (e.g. powdered- and granulated activated carbon) if an immobilized, continuous $\mathrm{H}_{2}$ production system is to be implemented [30,31].

According to literature reports, pretreated inocula are more often than not dominated by spore-forming and robust $\mathrm{H}_{2}$ producer species such as Clostridium sp. [13]; however some organisms of no utility (e.g. propionic acid and homoacetogenic bacteria) may also survive and reclaim their niche over time $[21,25]$. Changes in the microbial background can be revealed by the modern technical apparatus of molecular biology [32,33].

Furthermore, it is presumable that the age of the seed source most commonly sewage or biogas (anerobic fermenter) sludge as suggested by Tables 1 and 2 - may also be a factor to take into account. It is assumable that the microbial community structure of anaerobic mixed cultures varies constantly during storage due to changes (e.g. concentration differences) within microenvironments. Consequently, aging of an anaerobic seed culture over time can result in the variation of the obtainable bacterial populations and their activity. Thus, it might lead to alterations in the attainable biohydrogen performances even though standardized, identical pretreatment conditions are ensured time after time to prepare $\mathrm{H}_{2}$ producing inocula.

Moreover, beyond the goal of activating $\mathrm{H}_{2}$-producer organisms $[16,34,35]$, preliminary cultivation - mostly in batch - may also serve as a tool to acclimatize the microflora to certain substrates and their loadings e.g. to overcome inhibitory effect [36], which will induce a dynamic competition between the various groups of bacteria. Although batch-continuous start-up strategy was proposed by various authors to follow (for examples, please refer to Tables 1 and 2), some researchers reported adequate start-up directly in continuous operation [37-41].

The advantage of this strategy lacking initial discontinuous cell growth might be that in batch operation the nutrient concentrations as the time passes, especially at the end hours of the cycle, are insufficiently low and consequently a shift in the dominant strains could occur, depressing $\mathrm{H}_{2}$ production [12]. During careful continuous adaptation, broth is constantly supplemented and such disadvantageous phenomenon may be avoided. Moreover, continuous (hydraulic detention time influenced) acclimatization strategy encompasses the so-called biokinetic control which causes the 
Table 1

Start-up experiences during $\mathrm{H}_{2}$ fermentation in CSTR.

\begin{tabular}{|c|c|c|c|c|c|c|c|}
\hline $\begin{array}{l}\text { Reactor } \\
\text { type }\end{array}$ & Inoculum & $\begin{array}{l}\text { Inoculum } \\
\text { Pretreatment }\end{array}$ & Substrate & $\mathrm{pH}$ & $\begin{array}{l}T \\
\left({ }^{\circ} \mathrm{C}\right)\end{array}$ & Start-up experiences & Reference \\
\hline CSTR & $\begin{array}{l}5 \text { Different } \\
\text { thermophilic } \\
\text { sludge }\end{array}$ & - & Starch & N.C. & 55 & $\begin{array}{l}\text { Continuous feeding was started after obtaining exponential growth } \\
\text { phase in batch operation. Stable hydrogen production was attained in } \\
\text { less than } 30 \text { days of start-up }\end{array}$ & [70] \\
\hline CSTR & $\begin{array}{l}\text { Indigenous } \\
\text { microflora of } \\
\text { substrate }\end{array}$ & - & $\begin{array}{l}\text { Sweet sorghum } \\
\text { extract }\end{array}$ & $3.5-6.5$ & $35 \mathrm{C}$ & $\begin{array}{l}24 \mathrm{~h} \text { in batch mode to activate the indigenous microflora contained in } \\
\text { substrate }\end{array}$ & [74] \\
\hline CSTR & $\begin{array}{l}\text { Anaerobic digester } \\
\text { sludge }\end{array}$ & $\begin{array}{l}\text { Heat shock }\left(85^{\circ} \mathrm{C} \text {, }\right. \\
45 \mathrm{~min})\end{array}$ & $\begin{array}{l}\text { Cheese whey } \\
\text { wastewater }\end{array}$ & 5.5 & 55 & $\begin{array}{l}2 \text { days in batch mode, conversion to continuous operation when } \\
\text { hydrogen production reached its peak value }\end{array}$ & [75] \\
\hline CSTR & E. coli & - & Na-formate & 6.5 & 37 & Batch operation until exponential growth phase took place & [20] \\
\hline CSTR & $\begin{array}{l}\text { Anaerobic granular } \\
\text { sludge }\end{array}$ & $\begin{array}{l}\text { Heat shock (boiling } \\
\text { for } 40 \mathrm{~min} \text { ) }\end{array}$ & Cheese whey & 7.5 & 37 & Batch operation for $12 \mathrm{~h}$ & [49] \\
\hline CSTR & Digester sludge & N.M. & Cellulose & N.C. & 70 & 90 days until steady-state & [72] \\
\hline CSTR & $\begin{array}{l}\text { Waste activated } \\
\text { sludge }\end{array}$ & $\begin{array}{l}\text { Heat shock }\left(70^{\circ} \mathrm{C} \text {, }\right. \\
30 \mathrm{~min})\end{array}$ & Glucose & $5.5-6.5$ & 37 & $15 \mathrm{~h}$ in batch mode, 10 days to reach steady-state & [39] \\
\hline CSTR & $\begin{array}{l}\text { Anaerobic digester } \\
\text { sludge }\end{array}$ & N.M. & $\begin{array}{l}\text { Sugarbeet water } \\
\text { extract }\end{array}$ & 5.2 & 32 & $\begin{array}{l}\text { Continuous operation was commenced once significant hydrogen } \\
\text { production occurred }\end{array}$ & [76] \\
\hline CSTR & $\begin{array}{l}\text { Anaerobic digester } \\
\text { sludge }\end{array}$ & $\begin{array}{l}\text { Heat shock }\left(90^{\circ} \mathrm{C} \text {, }\right. \\
20 \mathrm{~min})\end{array}$ & L. japonica & $5.5-8$ & 35 & $\begin{array}{l}\text { When the yield reached } 60 \mathrm{~mL} \mathrm{H}_{2} / \mathrm{g} \mathrm{dcw} \text {, the operation was shifted to } \\
\text { continuous mode }\end{array}$ & [78] \\
\hline CSTR & $\begin{array}{l}\text { Anaerobic digester } \\
\text { sludge }\end{array}$ & $\begin{array}{l}\text { Heat shock }\left(90^{\circ} \mathrm{C} \text {, }\right. \\
10 \mathrm{~min})\end{array}$ & Food waste & 5.3 & 35 & $\begin{array}{l}\text { When cumulative } \mathrm{H}_{2} \text { production was equivalent to } 0.5 \mathrm{~mol} \mathrm{H}_{2} / \mathrm{mol} \\
\text { hexose, the reactors were put into continuous mode }\end{array}$ & [15] \\
\hline CSTR & $\begin{array}{l}\text { Anaerobic digester } \\
\text { sludge }\end{array}$ & $\begin{array}{l}\text { Heat shock }\left(90^{\circ} \mathrm{C} \text {, }\right. \\
15 \text { min })\end{array}$ & Sucrose & 5.3 & 35 & 20 days long start-up & {$[47]$} \\
\hline CSTR & $\begin{array}{l}\text { Wastewater } \\
\text { treating sludge }\end{array}$ & $\begin{array}{l}\text { Heat shock }\left(100{ }^{\circ} \mathrm{C} \text {, }\right. \\
45 \mathrm{~min})\end{array}$ & Starch & 5.5 & 35 & $\begin{array}{l}\text { Continuous feeding started after } 24 \mathrm{~h} \text { of batch operation. During start- } \\
\text { up, decreased initial organic loading rate could enhance hydrogen } \\
\text { production efficiency }\end{array}$ & [48] \\
\hline CSTR & Wastewater sludge & $\begin{array}{l}\text { Heat shock }\left(100{ }^{\circ} \mathrm{C} \text {, }\right. \\
45 \mathrm{~min})\end{array}$ & Sucrose & 6 & 35 & $\begin{array}{l}\text { The fermenter was first operated in a batch mode for two days and } \\
\text { then switched to a continuous operation }\end{array}$ & [63] \\
\hline CSTR & $\begin{array}{l}\text { Indigenous } \\
\text { microflora of } \\
\text { substrate }\end{array}$ & - & Cheese whey & 5.2 & 35 & $\begin{array}{l}\text { For start-up, the reactor was operated in batch mode for } 24 \mathrm{~h} \text { to } \\
\text { activate the indigenous microflora contained in the seed before } \\
\text { initiation of continuous operation }\end{array}$ & [34] \\
\hline CSTR & $\begin{array}{l}\text { Anaerobic digester } \\
\text { sludge }\end{array}$ & N.M. & Whey permeate & $4-5$ & $\begin{array}{l}35- \\
38\end{array}$ & Continuous bioreactors were operated as a batch for the first $40 \mathrm{~h}$ & [79] \\
\hline CSTR & $\begin{array}{l}\text { Anaerobic digester } \\
\text { sludge }\end{array}$ & $\begin{array}{l}\text { Heat and acid } \\
\text { treatment }\left(98^{\circ} \mathrm{C} \text {, }\right. \\
2 \mathrm{~h} ; \mathrm{pH}=2,24 \mathrm{~h})\end{array}$ & Glucose & 5.5 & 37 & $\begin{array}{l}1 \text { day in batch mode before continuous operation, Steady gas } \\
\text { production was observed after } 19 \text { days }\end{array}$ & [66] \\
\hline CSTR & Sewage sludge & - & $\begin{array}{l}\text { Terephthalic } \\
\text { acid processing } \\
\text { wastewater }\end{array}$ & 6 & 35 & Stabilized gas production was achieved after 25 days & [46] \\
\hline
\end{tabular}

N.M.: not mentioned; N.C.: not controlled.

wash out of existing microbes possessing inadequately low growth rates or adaption capabilities [42]. In other words, feeding regime affects the culture diversity and the relative abundance of the bacterial species.

Additionally, $\mathrm{pH}$, temperature and ORP adjustment are also of crucial importance, since their values change the generation time, growth rate and metabolic pathways of microorganisms present in a mixed culture [12,43-45]. It was also demonstrated that sustained continuous hydrogen formation could be achieved with a start-up strategy completely lacking preliminary inocula pretreatment and batch propagation. For example, bioreactor inoculated with untreated consortia achieved the suppression of $\mathrm{H}_{2}$ consuming microorganisms through the simultaneous enrichment of biohydrogen producers, taking place because of the insistent acidophilic microenvironment maintained from the beginning of operation [46]. For more studies skipping inocula pretreatment, the reader is referred to Tables 1 and 2 .

Besides the adequate substrate composition and loading, temperature, $\mathrm{pH}$ and OPR there are other parameters such as hydrogen partial pressure in the bioreactor that may need a control since it is a potential threat that hydrogenotrophic consortial activity may be provoked under high $\mathrm{H}_{2}$ concentrations [25]. From another point of view, reduced $\mathrm{H}_{2}$ partial pressure was proven to increase hydrogenase activity and making $\mathrm{H}_{2}$ formation thermodynamically favorable [47].

\subsection{Switch-over time}

Since the establishment of continuous hydrogen fermentation implicates an initiative batch cycle for most cases, another issue to be discussed is its duration.

The literature is not consistent about this question, or in other words, it is not fully obvious when to convert to continuous hydrogen fermentation. However, as listed in Tables 1 and 2, the following strategies could be identified as the most popular ones:

- switch-over when significant biohydrogen production commences,

- switch-over when reaching the exponential $\mathrm{H}_{2}$ production phase, and

- switch-over after a few days of batch cultivation.

Regardless the hydrogen fermentation system employed, dilution rate, substrate loading intensity, $\mathrm{pH}$ and temperature applied during transition-state (caused by the switch between batch and continuous operation) reactor run will result in the enrichment of certain bacterial populations and moreover, these factors inherently direct their metabolic pathways. After a period of time when the functional consortia got used to the environmental conditions and consequently stabilized, steady-state can take place which is mostly considered to reach when variations in $\mathrm{H}_{2}$ gas production, $\mathrm{pH}$ and effluent (spent media) quality 
Table 2

Start-up experiences during $\mathrm{H}_{2}$ fermentation in reactors other than CSTR.

\begin{tabular}{|c|c|c|c|c|c|c|c|}
\hline $\begin{array}{l}\text { Reactor } \\
\text { type }\end{array}$ & Inoculum & $\begin{array}{l}\text { Inoculum } \\
\text { Pretreatment }\end{array}$ & Substrate & $\mathrm{pH}$ & $\mathrm{T}$ & Start-up experiences & Reference \\
\hline UASBR & $\begin{array}{l}\text { Mixture of } \\
\text { precultured and } \\
\text { granulated sludge }\end{array}$ & $\begin{array}{l}\text { Heat shock }\left(100^{\circ} \mathrm{C} \text {, }\right. \\
2 \mathrm{~h})\end{array}$ & Starch & 5 & 55 & $\begin{array}{l}\text { After confirming the exponential production of the biogas, the } \\
\text { operation was turned into continuous mode }\end{array}$ & [73] \\
\hline UASBR & Sewage sludge & $\begin{array}{l}\text { Heat shock }\left(100^{\circ} \mathrm{C} \text {, }\right. \\
45 \mathrm{~min})\end{array}$ & Sucrose & 6.7 & 35 & $\begin{array}{l}\text { Time-consuming start-up, almost } 40 \text { days were taken to reach steady- } \\
\text { state }\end{array}$ & [52] \\
\hline AFBR & $\begin{array}{l}\text { Wastewater } \\
\text { treating sludge }\end{array}$ & $\begin{array}{l}\text { Heat shock }\left(90^{\circ} \mathrm{C}\right. \\
15 \mathrm{~min})\end{array}$ & $\begin{array}{l}\text { Glucose, cheese } \\
\text { whey }\end{array}$ & N.M. & 30 & $\begin{array}{l}\text { Initially, the reactors were operated as batch for } 76 \mathrm{~h} \text { prior to switching } \\
\text { to continuous mode }\end{array}$ & [29] \\
\hline $\begin{array}{r}\text { UASBR, } \\
\text { CSTR }\end{array}$ & $\begin{array}{l}\text { Anaerobic digester } \\
\text { sludge }\end{array}$ & $\begin{array}{l}\text { Heat shock }\left(90^{\circ} \mathrm{C}\right. \\
20 \mathrm{~min})\end{array}$ & $\begin{array}{l}\text { Coffee drink } \\
\text { manufacturing } \\
\text { wastewater }\end{array}$ & 5.5 & 35 & $\begin{array}{l}\text { Continuous operation was delayed until a yield of } 0.5 \mathrm{~mol} \mathrm{H}_{2} / \mathrm{mol} \\
\text { hexose achieved in the batch, start-up took } 10 \text { days in continuous mode }\end{array}$ & [77] \\
\hline UASBR & $\begin{array}{l}\text { Anaerobic digester } \\
\text { sludge }\end{array}$ & $\begin{array}{l}\text { Heat shock }\left(90^{\circ} \mathrm{C}\right. \\
20 \mathrm{~min})\end{array}$ & $\begin{array}{l}\text { Coffee drink } \\
\text { manufacturing } \\
\text { wastewater }\end{array}$ & 5.5 & 35 & $\begin{array}{l}\text { When the yield of produced } \mathrm{H}_{2} \text { reached } 0.5 \mathrm{~mol} \mathrm{H}_{2} / \mathrm{mol} \text { hexose, } \\
\text { continuous operation started }\end{array}$ & [59] \\
\hline ASBR & $\begin{array}{l}\text { Anaerobic digester } \\
\text { sludge }\end{array}$ & $\begin{array}{l}\text { Heat shock }\left(90^{\circ} \mathrm{C}\right. \\
10 \mathrm{~min})\end{array}$ & Food waste & 5.3 & 35 & $\begin{array}{l}\text { When cumulative } \mathrm{H}_{2} \text { production of } 0.5 \mathrm{~mol} \mathrm{H}_{2} / \mathrm{mol} \text { hexose was } \\
\text { observed, the reactors were put into continuous operation. Steady-state } \\
\text { was reached in 10-30 days depending on the HRT and inoculation } \\
\text { conditions }\end{array}$ & [57] \\
\hline AFBR & $\begin{array}{l}\text { Wastewater } \\
\text { treating sludge }\end{array}$ & $\begin{array}{l}\text { Heat shock }\left(90^{\circ} \mathrm{C} \text {, }\right. \\
10 \mathrm{~min})\end{array}$ & Glucose & N.C. & 30 & $\begin{array}{l}\text { The bioreactor was initially run as a batch for } 2 \text { days to stimulate the } \\
\text { hydrogen-producing biomass }\end{array}$ & [16] \\
\hline ABR & $\begin{array}{l}\text { Anaerobic digester } \\
\text { sludge }\end{array}$ & $\begin{array}{l}\text { Heat shock }\left(105^{\circ} \mathrm{C} \text {, }\right. \\
2 \mathrm{~h})\end{array}$ & $\begin{array}{l}\text { Tapioca } \\
\text { wastewater }\end{array}$ & $\begin{array}{l}6.5^{\mathrm{a}} \\
9^{\mathrm{b}}\end{array}$ & 32 & $\begin{array}{l}\text { Multistep batch operation and gradual acclimatization of mixed } \\
\text { consortia to substrate. First } 3 \text { days in batch operation. } 37 \text { days were } \\
\text { required to reach steady-state } \mathrm{H}_{2} \text { production }\end{array}$ & [64] \\
\hline ASBR & $\begin{array}{l}\text { Anaerobic digester } \\
\text { sludge }\end{array}$ & $\begin{array}{l}\text { Heat shock }\left(100^{\circ} \mathrm{C} \text {, }\right. \\
30 \mathrm{~min})\end{array}$ & $\begin{array}{l}\text { Liquid swine } \\
\text { manure mixed } \\
\text { with glucose }\end{array}$ & 5 & 37 & $\begin{array}{l}\text { Firstly, the bioreactor was operated in a batch mode for } 24 \mathrm{~h} \text { until the } \\
\text { established biogas production took place }\end{array}$ & {$[56]$} \\
\hline ASBR & $\begin{array}{l}\text { Anaerobic digester } \\
\text { sludge }\end{array}$ & $\begin{array}{l}\text { Heat shock (boiled, } \\
30 \mathrm{~min} \text { ) }\end{array}$ & $\begin{array}{l}\text { Liquid swine } \\
\text { manure mixed } \\
\text { with glucose }\end{array}$ & $\begin{array}{l}5^{\mathrm{a}} \\
4.4- \\
5.6^{\mathrm{b}}\end{array}$ & 37 & $\begin{array}{l}\text { Firstly, the bioreactor was operated in a batch mode for } 24 \mathrm{~h} \text { until } \\
\text { established biogas production took place }\end{array}$ & [58] \\
\hline UASBR & $\begin{array}{l}\text { Enriched } \\
\text { facultative } \\
\text { anaerobic culture }\end{array}$ & $\begin{array}{l}\text { Enriched culture } \\
\text { with Clostridium } \\
\text { pasteurianum }\end{array}$ & $\begin{array}{l}\text { Citric acid } \\
\text { wastewater }\end{array}$ & 7 & $\begin{array}{l}35- \\
38\end{array}$ & $\begin{array}{l}\text { More than a month long acclimatization before starting continuous } \\
\text { mode. UASB start-up took } 20 \text { days, excellent system stabilization }\end{array}$ & {$[55]$} \\
\hline UASBR & $\begin{array}{l}\text { Wastewater } \\
\text { treating sludge }\end{array}$ & N.M. & Sucrose & $\begin{array}{l}6.1- \\
9.5\end{array}$ & 39 & $\begin{array}{l}\text { The start-up of the UASB reactor lasted for } 300 \text { days to enrich } \mathrm{H}_{2-} \\
\text { producing microbes and establish a stable gas generation. Afterwards, } \\
\text { a successful operation was achieved with the formation of the } \mathrm{H}_{2^{-}} \\
\text {producing granules }\end{array}$ & [53] \\
\hline
\end{tabular}

ABR: anaerobic baffled reactor; AFBR: anaerobic fluidized bed reactor; N.M.: not mentioned; N.C.: not controlled.

${ }^{a}$ During start-up.

b After start-up.

e.g. in terms of soluble metabolic product (SMP) distribution and related concentrations are below $10 \%$ on a daily average base [48].

Therefore, appropriate threshold levels of the parameters mentioned can develop an attractive hydrogen-generating biocommunity and govern the whole bioreactor towards better performances e.g. volumetric production rates and yields [49].

\subsection{Bioreactor configuration}

The configuration of the bioreactor set-up is also a concern to keep in mind since different kinds of reactors can be characterized by distinct start-up stage features, for example in terms of its duration $[6,14]$. Nowadays, the suspended-cell, completely stirred tank reactor (CSTR) is the most routinely applied one, however, up-flow anaerobic sludge blanket (UASBR) reactors, anaerobic membrane bioreactors and immobilized (e.g. fluidized bed) bioreactors [16,29] became popular due to their improved $\mathrm{H}_{2}$ producing potentials.

Generally, the CSTR is featured by a relatively short induction phase [50] as compared to other applications (e.g. UASBR) due to better mass transfer, but it needs rigorous supervision due to the disposition of cells to wash out at inadequate operating bioreactor regimen. Troubleshooting the risk of wash out can be performed by biomass-rejective systems such as the membrane bioreactors [6] or immobilized e.g. fixed bed systems [51,70]. These alternatives may demonstrate more robust operation and enhanced hydrogen production efficiency even in smaller reactor volumes that is of economical importance.

Another option is the usage of UASBR. Basically, this construction is described by extended start-up phase $[52,53]$ since the flocculation of bacterial communities in the sludge-bed demands longer time. However, start-up period of granular systems for biohydrogen generation could be considerably shortened through the transformation of methanogenic granules (obtained e.g. from already existing and well-established anaerobic, methane forming UASB reactors) into hydrogen producing ones, as recently reported [54].

An important trait of UASBR is the fact that it does not apply mechanical mixing and therefore $\mathrm{pH}$ gradients can occur which is not easy to control. For pH regulation purposes, the buffer capacity of the fermentation media may be adjusted to withstand progressive $\mathrm{pH}$ depression caused by the formation of acidic by-products that is always expectable in parallel to $\mathrm{H}_{2}$ bioproduction. However, in return to laborious start-up, granulated reactors reflect remarkably improved operational stability [55]. This is because granulation reactors enhance the active biomass concentration and thereby able to sustain under increased substrate dosage and greater dilution rates so that higher $\mathrm{H}_{2}$ production intensity can be accomplished [56].

Last but not least, the anaerobic sequencing batch reactor is also among the available design options for continuous $\mathrm{H}_{2}$ fermentation [56-58]. 


\section{Experiences and lessons of continuous $\mathrm{H}_{2}$ producing bioreactor start-up}

Alternatively to the strategy described in [54], it has been reported that the start-up time of UASBR could also be significantly decreased by thriving $\mathrm{H}_{2}$-producing cells in CSTR arrangement prior to transferring them to the up-flow anaerobic sludge blanket reactor as seeding source [59]. As it was found, despite the high shearing forces in CSTR, self-flocculation of hydrogengenerating bacteria was notably faster than in UASBR and explained by the more intense mass transfer capacity of the former reactor type.

Besides, organic loading rate fluctuation was reported to accelerate the start-up process both in suspended- and immobilized cell applications [31]. This strategy was shown as an efficient way to rapidly and effectively establish a good biohydrogen evolver culture and less than 3 weeks were required to obtain stabilized operation, which is considerably shorter in comparison with other similar systems [60].

In relation to start-up duration, anaerobic sequencing batch reactor (ASBR) was demonstrated as a feasible concept to provide quick steady-state. Studies indicated that start-up time requirements in the range of 12-14 days were far below the values revealed for UASBR and CSTR [56,61].

As communicated [62], operational conditions employed in UASBR start-up could have significant impact on the microbial fingerprint of mixed $\mathrm{H}_{2}$ producing sludge, depending on the seed inocula structure.

Likewise, $\mathrm{pH}$ adjustment was noticed to express marked influence during $\mathrm{H}_{2}$-formation bioreactor start-up [46,58]. It has appeared that $\mathrm{pH}$ values out of optimal range may induce population- and metabolic shifts (i.e. solventgenesis). Moreover, the hydrogenase enzyme activity and growth rate of microorganism responsible for $\mathrm{H}_{2}$ fermentation can also be hindered under inappropriate $\mathrm{pH}$ conditions. Hence, non-optimal $\mathrm{pH}$ probably causes an unambiguous delay in attaining steady-state conditions with the desired $\mathrm{H}_{2}$ production rate and yield.

Moreover, pre-culturing seed inocula and initial batch strategy were observed to be efficient start-up concept that supported biomass growth and consistent $\mathrm{H}_{2}$ production well in subsequent continuous operation [63]. The adaption of $\mathrm{H}_{2}$ producing microflora to a given substrate can be conducted in complex and multistep batch operation, where bacterial consortia are periodically supplied with gradually increasing feed concentrations before putting into continuous mode [64]. Nevertheless, as mentioned above, there are studies that skipped preliminary batch operation and adapted the $\mathrm{H}_{2}$ generating cultures during continuous operation. Regarding these start-up strategies, it is to conclude that the hydraulic retention time (HRT) is usually stepwise refined from long to short time intervals to allow the acclimatization of microorganisms to new environments and prevent washing out the bacteria of interest [65]. As a result of shifting HRT, the microbial population dynamically changes leading to the disappearance of certain species while others show up [66].

Additionally to HRT, altering organic loading rate (OLR) is also a stress source to the strains that are forced to get accustomed to new surroundings [52]. Varying OLR might cause sporulation in hydrogen producing cultures and contribute to the observable fluctuations in the $\mathrm{H}_{2}$ production efficacy during start-up stage $[48,67]$.

It is an ongoing progress in biohydrogen research that various waste substances are utilized to improve process viability. However, depending on the nature of these problematic raw materials (e.g. cheese whey), it is presumptive that they contain indigenous microflora which of course, from the beginning, might affect bioreactor performance in a negative manner [75]. In this regard, it was evaluated [15] that attention should be paid to the pretreatment (e.g. by means of alkali) and sufficient storage circumstances (preferentially at cold temperature) of such streams. This is attributed to the fact that indigenous strains, for example non- $\mathrm{H}_{2}$-producing acidogens such as lactic- and propionic bacteria present in non-aseptic substrate could cause strong contamination and even outcompete the $\mathrm{H}_{2}$-producing microbes [68,69].

Even though the biosystems may resist the perturbations caused by contamination and might be able to express the performance required, dominance of disadvantageous nonhydrogen producing bacteria potentially leads to problematic start-up, unsuccessful continuous operation in long terms and consequently may force to reinoculate and restart the $\mathrm{H}_{2}$ fermenting bioreactor.

Recently, it was experimentally demonstrated that nonhydrogen producing cells, as a result of long batch cultivation, were promoted alongside their useful $\mathrm{H}_{2}$ evolver counterparts and could take over, causing tough start-up failure. In order to avoid such undesired microbiological activity, an early switch-over time was recommended that highly increased the chance of successful and long-term continuous $\mathrm{H}_{2}$ fermentation [69]. It is also extractable from the literature that inocula source can be a determining factor of the time necessary for starting-up a continuous $\mathrm{H}_{2}$ producing fermenter [70].

In addition to contamination related issues, operational failures caused by unforeseen technical difficulties (e.g. broken pumps, leaking tubes) may also challenge the adequate start-up since they can cause insufficient or shocking organic loading rates, altered hydraulic detention times and thus, disturb the developing microbial consortia and affect its survivability.

To aid bioreactor start-up, monitoring the soluble metabolites such as volatile fatty acids is apparently beneficial. The ratios of acetic-, butyric-, and propionic acids produced by the various groups of microorganisms can be useful feedbacks about the state of the hydrogen producing consortia. When propionic acid concentration gradually increases in fermentation broth, it assumes the occurrence of microbes with no utility for $\mathrm{H}_{2}$ production and gives the sign that troubleshooting of the reactor is required to avoid strong deterioration of its performance.

In cases when an unusual decline in hydrogen production efficiency occurs (e.g. as a consequence of population shift or appearance of methanogenic activity) during start-up that threats achieving steady-state, a temperature shift strategy may be carried out which includes heating the bioreactor to higher temperature ranges (e.g. to $70-80{ }^{\circ} \mathrm{C}$ ) for a short time (e.g. $1 \mathrm{~h}$ ) to reclaim hydrogen producing bacteria and reactor performance [71]. However, it may be ineffective for granulated systems, since it was proven that granules serve as protective structure. In such cases, disintegration of granules prior to temperature shift or combined methods (e.g. temperature- and $\mathrm{pH}$ shift together) might work [62]. On the contrary, it was demonstrated that simple washing and subsequent boiling of granular sludge could be a feasible approach to inactivate hydrogen consuming microorganisms [49].

It is to mention that process temperature - even in the same bioreactor design - could influence the reactor behavior during start-up. As a matter of fact, comparison of meso- and (hyper) thermophilic $\mathrm{H}_{2}$ production in CSTRs indicates that start-up of the latter group could last as long as 90 days to achieve stabilized $\mathrm{H}_{2}$ fermentation [72], while mesophilic $\mathrm{H}_{2}$ production in similar system configurations was reported to reach steady-state circumstances in shorter times $[39,47,67]$.

As a summary, the flow chart depicted in Fig. 1 presents the connection network of the various steps involved in continuous hydrogen producing bioreactor start-up. 


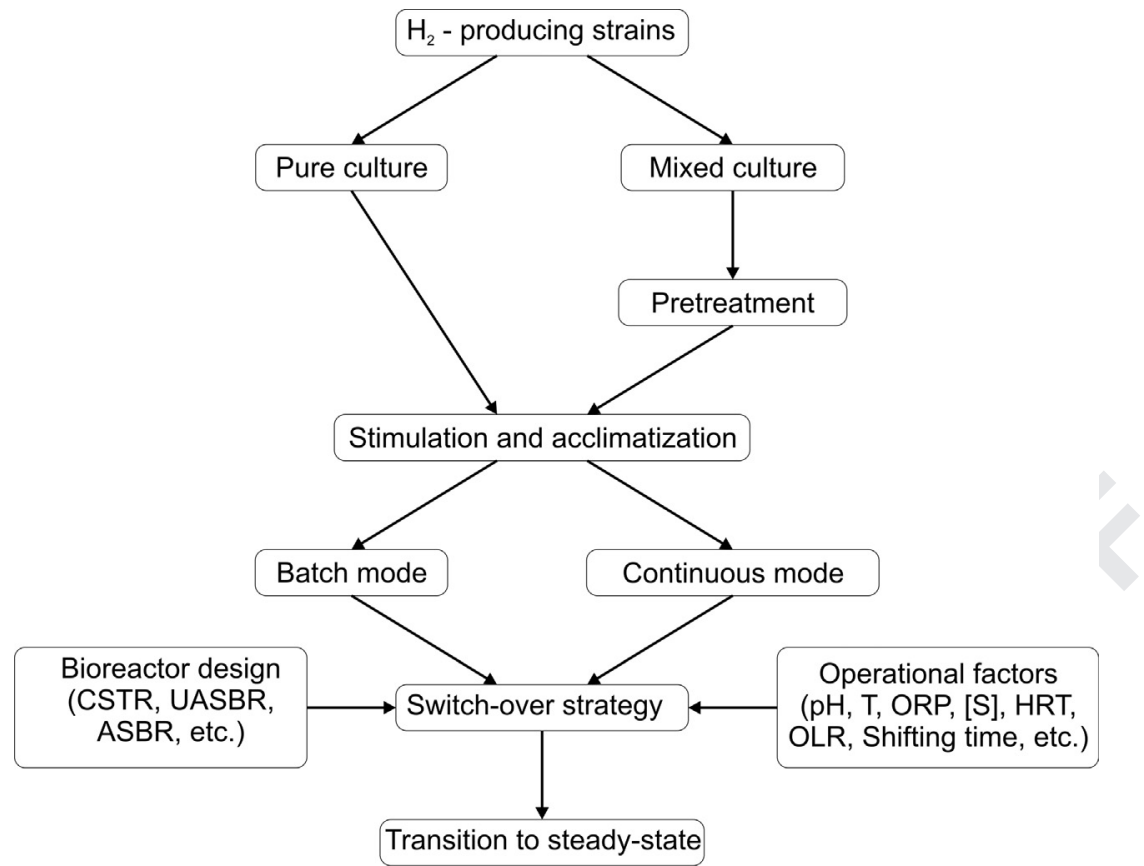

Fig. 1. Flow chart illustrating the various steps of start-up process.

\section{Conclusions}

In this review, the experiences of continuous hydrogen fermentation start-up were scoped and analyzed. The lessons of relevant literature papers about the routes leading to continuous and efficient, steady-state hydrogen production imply that startup is of high concern to avoid significant performance losses. As a general guideline, the establishment of reliable, continuous hydrogen producing bioreactors should start with proper inocula selection and its pretreatment (if necessary), followed by an acclimatization period - conducted mainly as a batch - to adopt the living biocatalysts to the intended substrate which may also require preliminary treatment to eliminate native and undesirable microflora present in it. Subsequently, switch-over strategy assigned to ensure viable and smooth batch to continuous shift - must be designed e.g. timed properly in order to preserve and ensure microorganism with as high hydrogen producing capacity as possible. Besides timing, transition from batch to continuous mode hydrogen fermentation should take also into account the suitable adjustment of major environmental (physiological) factors - such as pH, temperature, etc. - and the operating conditions (e.g. hydraulic retention time, organic loading rate, etc.) applied with respect to bioreactor configuration (CSTR, UASB, AnMBR, etc.). Currently, CSTRs are the most widely used reactors for continuous hydrogen production due to their relatively rapid start-up phase. Nevertheless, as a result of the efforts made to cut start-up time demand of other devices, more wide-spread employment of granular- and immobilized systems and that of reactors integrated with downstream (membrane bioreactors) is presumable in the future, which is also attributed to their potential benefits (e.g. higher long-term performance and enhanced stress tolerance) over the conventional set-ups.

\section{Acknowledgments}

Péter Bakonyi thanks the TÁMOP 4.2.4.A/2-11-1-2012-0001 'National Excellence Program' supported by the European Union and the State of Hungary, co-financed by the European Social
Fund. Nándor Nemestóthy acknowledges the János Bolyai Research Scholarship of the Hungarian Academy of Sciences. The research infrastructure was supported by TÁMOP 4.2.2/A-11/1/KONV-20120071 financed by the European Union and the European Social Fund.

\section{References}

[1] Azwar MY, Hussain MA, Abdul-Wahab AK. Development of biohydrogen production by photobiological, fermentation and electrochemical processes: a review. Renew Sustain Energy Rev 2014;31:158-73.

[2] Ren NQ, Guo WQ, Liu BF, Cao GL, Ding J. Biological hydrogen production by dark fermentation: challenges and prospects towards scaled-up production. Curr Opin Biotechnol 2011;22:365-70.

[3] Cheng CL, Lo YC, Lee KS, Lee DJ, Lin CY, Chang JS. Biohydrogen production from lignocellulosic feedstock. Bioresour Technol 2011;102:8514-23.

[4] Guo XM, Trably E, Latrille E, Carrére H, Jean-Philippe S. Hydrogen production from agricultural waste by dark fermentation: a review. Int J Hydrog Energy 2010;34:10660-73.

[5] Lin CY, Lay CH, Sen B, Chu CY, Kumar G, Chen CC, et al. Fermentative hydrogen production from wastewaters: a review and prognosis. Int J Hydrog Energy 2012:37:15632-42.

[6] Bakonyi P, Nemestóthy N, Simon V, Bélafi-Bakó K. Fermentative hydrogen production in anaerobic membrane bioreactors: a review. Bioresour Technol 2014;156:357-63.

[7] Bakonyi P, Nemestóthy N, Bélafi-Bakó K. Biohydrogen purification by membranes: an overview on the operational conditions affecting the performance of non-porous, polymeric and ionic liquid based gas separation membranes. Int J Hydrog Energy 2013;38:9673-87.

[8] Bakonyi P, Kumar G, Nemestóthy N, Lin CY, Bélafi-Bakó K. Biohydrogen purification using a commercial polyimide membrane module: studying the effects of some process variables. Int J Hydrog Energy 2013;38:15092-9.

[9] Ramírez-Morales JE, Tapia-Venegas E, Nemestóthy N, Bakonyi P, Bélafi-Bakó K, Ruiz-Filippi G. Evaluation of two gas membrane modules for fermentative hydrogen separation. Int J Hydrog Energy 2013;38:14042-52.

[10] Hallenbeck PC, Ghosh D. Advances in fermentative biohydrogen production: the way forward? Trends Biotechnol 2009;27:287-97.

[11] Wang J, Wan W. Factors influencing fermentative hydrogen production: a review. Int J Hydrog Energy 2009;34:799-811.

[12] Hawkes FR, Dinsdale R, Hawkes DL, Hussy I. Sustainable fermentative hydrogen production: challenges for process optimisation. Int J Hydrog Energy 2002;27:1339-47.

[13] Hawkes FR, Hussy I, Kyazze G, Dinsdale R, Hawkes DL. Continuous dark fermentative hydrogen production by mesophilic microflora: principles and progress. Int J Hydrog Energy 2007;32:172-84.

[14] Jung KW, Kim DH, Kim SH, Shin HS. Bioreactor design for continuous dark fermentative hydrogen production. Bioresour Technol 2011;102:8612-20. 
[15] Kim SH, Shin HS. Effects of base-pretreatment on continuous enriched culture for hydrogen production from food waste. Int J Hydrog Energy 2008;33:5266-74.

[16] Shida GM, Barros AR, Reis DCM, Amorim ELCD, Damianovic MHRZ, Silva ED. Long-term stability of hydrogen and organic acids production in an anaerobic fluidized-bed reactor using heat treated anaerobic sludge inoculum. Int J Hydrog Energy 2009;34:3679-88.

[17] Hernández-Mendoza CE, Moreno-Andrade I, Buitrón G. Comparison of hydrogen-producing bacterial communities adapted in continuous and discontinuous reactors. Int J Hydrog Energy 2014. http://dx.doi.org/10.1016/j. ijhydene.2014.01.014.

[18] Lee DJ, Show KY, Su A. Dark fermentation on biohydrogen production: pure culture. Bioresour Technol 2011;102:8393-402.

[19] Bakonyi P, Nemestóthy N, Lövitusz É, Bélafi-Bakó K. Application of PlackettBurman experimental design to optimize biohydrogen fermentation by $E$. coli (XL1-BLUE). Int J Hydrog Energy 2011;36:13949-54.

[20] Bakonyi P, Nemestóthy N, Ramirez J, Ruiz-Filippi G, Bélafi-Bakó K. Escherichia coli (XL1-BLUE) for continuous fermentation of $\mathrm{bioH}_{2}$ and its separation by polyimide membrane. Int J Hydrog Energy 2012;37:5623-30.

[21] Valdez-Vazquez I, Poggi-Varaldo HM. Hydrogen production by fermentative consortia. Renew Sustain Energy Rev 2009;13:1000-13.

[22] Wong YM, Wu TY, Juan JC. A review of sustainable hydrogen production using seed sludge via dark fermentation. Renew Sustain Energy Rev 2014;34: $471-82$.

[23] Pattra S, Lay CH, Lin CY, O-Thong S, Reungsang A. Performance and population analysis of hydrogen production from sugarcane juice by non-sterile continuous stirred tank reactor augmented with Clostridium butyricum. Int J Hydrog Energy 2011;36:8697-703.

[24] Hung CH, Chang YT, Chang YJ. Roles of microorganisms other than Clostridium and Enterobacter in anaerobic fermentative biohydrogen production systems a review. Bioresour Technol 2011;102:8437-44.

[25] Saady NMC. Homoacetogenesis during hydrogen production by mixed cultures dark fermentation: unresolved challenge. Int J Hydrog Energy 2013;38:13172-91.

[26] Bakonyi P, Borza B, Orlovits K, Simon V, Nemestóthy N, Bélafi-Bakó K. Fermentative hydrogen production by conventionally and unconventionally heat pretreated seed cultures: a comparative assessment. Int J Hydrog Energy 2014:39:5589-96.

[27] Ren NQ Guo WQ, Wang XJ, Xiang WS, Liu BF, Wang XZ, et al. Effects of different pretreatment methods on fermentation types and dominant bacteria for hydrogen production. Int J Hydrog Energy 2008;33:4318-24.

[28] Wang J, Wan W. Comparison of different pretreatment methods for enriching hydrogen-producing bacteria from digested sludge. Int J Hydrog Energy 2008:33:2934-41.

[29] Ferreira Rosa PR, Santos SC, Silva EL. Different ratios of carbon sources in the fermentation of cheese whey and glucose as substrates for hydrogen and ethanol production in continuous reactors. Int J Hydrog Energy 2014;39: 1288-96.

[30] Lee KS, Lin PJ, Chang JS. Temperature effects on biohydrogen production in a granular sludge bed induced by activated carbon carriers. Int J Hydrog Energy 2006;31:465-72.

[31] Ren NQ, Tang J, Liu BF, Guo WQ. Biological hydrogen production in continuous stirred tank reactor systems with suspended and attached microbial growth. Int J Hydrog Energy 2010;35:2807-13.

[32] Li RY, Zhang T, H.H.P. Fang. Application of molecular techniques on heterotrophic hydrogen production research. Bioresour Technol 2011;102:8445-56.

[33] Tolvanen KES, Karp MT. Molecular methods for characterizing mixed microbial communities in hydrogen-fermenting systems. Int J Hydrog Energy 2011:365280-8.

[34] Venetsaneas N, Antonopoulou G, Stamatelatou K, Kornaros M, Lyberatos G. Using cheese whey for hydrogen and methane generation in a two-stage continuous process with alternative $\mathrm{pH}$ controlling approaches. Bioresour Technol 2009;100:3713-7.

[35] Wu X, Lin H, Zhu J. Optimization of continuous hydrogen production from cofermenting molasses with liquid swine manure in an anaerobic sequencing batch reactor. Bioresour Technol 2013;136:351-9.

[36] Badiei M, Jahim JM, Anuar N, Abdullah SRS. Effect of hydraulic retention time on biohydrogen production from palm oil mill effluent in anaerobic sequencing batch reactor. Int J Hydrog Energy 2011;36:5912-9.

[37] Chen CC, Lin CY, Chang JS. Kinetics of hydrogen production with continuous anaerobic cultures utilizing sucrose as the limiting substrate. Appl Microbiol Biotechnol 2001:57:56-64.

[38] Cheng CH, Hung CH, Lee KS, Liau PY, Liang CM, Yang LH, et al. Microbial community structure of a starch-feeding fermentative hydrogen production reactor operated under different incubation conditions. Int J Hydrog Energy 2008;33:5242-9.

[39] Hafez H, Baghchehsaraee B, Nakhla G, Karamanev D, Margaritis A, Naggar HE. Comparative assessment of decoupling of biomass and hydraulic retention times in hydrogen production bioreactors. Int J Hydrog Energy 2009;34: 7603-11.

[40] Li J, Zheng G, He J, Chang S, Qin Z. Hydrogen-producing capability of anaerobic activated sludge in three types of fermentations in a continuous stirred-tank reactor. Biotechnol Adv 2009:27:573-7.

[41] Lin CY, Wu CC, Hung CH. Temperature effects on fermentative hydrogen production from xylose using mixed anaerobic cultures. Int J Hydrog Energy 2008;33:43-50.
[42] Tapia-Venegas E, Ramirez JE, Donoso-Bravo A, Jorquera L, Steyer JP, RuizFilippi G. Bio-hyrogen production during acidogenic fermentation in a multistage stirred tank reactor. Int J Hydrog Energy 2013;38:2185-90.

[43] Ren NQ Zhao D, Chen X, Li J. Mechanism and controlling strategy of the production and accumulation of propionic acid for anaerobic wastewater treatment. Sci China Ser B 2002;45:319-27.

[44] Ren NQ Chua H, Chan SY, Tsang YF, Wang YJ, Sin N. Assessing optimal fermentation type for bio-hydrogen production in continuous-flow acidogenic reactors. Bioresour Technol 2007;98:1774-80.

[45] Wang L, Zhou Q, Li FT. Avoiding propionic acid accumulation in the anaerobic process for biohydrogen production. Biomass Bioenergy 2006;30:177-82.

[46] Biohydrogen production from purified terephthalic acid (PTA) processing wastewater by anaerobic fermentation using mixed microbial communities. In: Zhu GF, Wu P, Wei QS, Lin JY, Gao YL, Liu HN, editors. Int J Hydrog Energy, 35; 2010. p. 8350-6.

[47] Kim DH, Han SK, Kim SH, Shin HS. Effect of gas sparging on continuous fermentative hydrogen production. Int J Hydrog Energy 2006;31:2158-69.

[48] Lin CY, Chang CC, Hung CH. Fermentative hydrogen production from starch using natural mixed cultures. Int J Hydrog Energy 2008;33:2445-53.

[49] Davila-Vazquez G, Cota-Navarro CB, Rosales-Colunga LM, León-Rodríguez A Razo-Flores E. Continuous biohydrogen production using cheese whey: improving the hydrogen production rate. Int J Hydrog Energy 2009;34: 4296-304.

[50] Yuan Z, Yang H, Zhi X, Shen J. Increased performance of continuous stirred tank reactor with calcium supplementation. Int J Hydrog Energy 2010;35: 2622-6.

[51] Keskin T, Giusti L, Azbar N. Continuous biohydrogen production in immobilized biofilm system versus suspended cell culture. Int J Hydrog Energy 2012;37:1418-24.

[52] Chang FY, Lin CY. Biohydrogen production using an up-flow anaerobic sludge blanket reactor. Int J Hydrog Energy 2004;29:33-9.

[53] Zhao QB, Yu HQ. Fermentative $\mathrm{H}_{2}$ production in an upflow anaerobic sludge blanket reactor at various pH values. Biroresour Technol 2008;99:1353-8.

[54] Hernández-Mendoza CE, Buitrón G. Suppression of methanogenic activity in anaerobic granular biomass for hydrogen production. J Chem Technol Biotechnol 2014;89:143-9.

[55] Yang H, Shao P, Lu T, Shen J, Wang D, Xu Z, et al. Continuous bio-hydrogen production from citric acid wastewater via facultative anaerobic bacteria. Int J Hydrog Energy 2006;31:1306-13.

[56] Wu X, Zhu J, Dong C, Miller C, Li Y, Wang L, et al. Continuous biohydrogen production from liquid swine manure supplemented with glucose using an anaerobic sequencing batch reactor. Int J Hydrog Energy 2009;34:6636-45.

[57] Kim SH, Han SK, Shin HS. Optimization of continuous hydrogen fermentation of food waste as a function of solids retention time independent of hydraulic retention time. Process Biochem 2008:43:213-8.

[58] Wu X, Yao W, Zhu J. Effect of $\mathrm{pH}$ on continuous biohydrogen production from liquid swine manure with glucose supplement using an anaerobic sequencing batch reactor. Int J Hydrog Energy 2010;35:6592-9.

[59] Jung KW, Kim DH, Kim SH, Shin HS. A simple method to reduce the start-up period in a $\mathrm{H}_{2}$-producing UASB reactor. Int J Hydrog Energy 2011;36:1466-73.

[60] Wu SY, Hung CH, Lin CY, Lin PJ, Lee KS, Lin CN, et al. HRT-dependent hydrogen production and bacterial community structure of mixed anaerobic microflora in suspended, granular and immobilized sludge systems using glucose as the carbon substrate. Int J Hydrog Energy 2008;33:1542-9.

[61] Kim SH, Han SK, Shin HS. Performance comparison of a continuous-flow stirred-tank reactor and an anaerobic sequencing batch reactor for fermentative hydrogen production depending on substrate concentration. Water Sci Technol 2005;52:23-9.

[62] Carrillo-Reyes J, Celis LB, Alatriste-Mondragón F, Razo-Flores E. Different startup strategies to enhance biohydrogen production from cheese whey in UASB reactors. Int J Hydrog Energy 2012;37:5591-601.

[63] Lin CY, Wu SY, Lin PJ, Chang JS, Hung CH, Lee KS, et al. Pilot-scale hydrogen fermentation system start-up performance. Int J Hydrog Energy 2010;35: 13452-7.

[64] Thanwised P, Wirojanagud W, Reungsang A. Effect of hydraulic retention time on hydrogen production and chemical oxygen demand removal from tapioca wastewater using anaerobic mixed cultures in anaerobic baffled reactor (ABR). Int J Hydrog Energy 2012;37:15503-10.

[65] Chen CC, Lin CY. Start-up of anaerobic hydrogen producing reactors seeded with sewage sludge. Acta Biotechnol 2001;21:371-9.

[66] Zhang ZP, Show KY, Tay JH, Liang DT, Lee DJ, Jiang WJ. Effect of hydraulic retention time on biohydrogen production and anaerobic microbial community. Process Biochem 2006:41:2118-23.

[67] Lin CY, Cheng CH. Fermentative hydrogen production from xylose using anaerobic mixed microflora. Int J Hydrog Energy 2006;31:832-40.

[68] Jo JH, Jeon CO, Lee DS, Park JM. Process stability and microbial community structure in anaerobic hydrogen-producing microflora from food waste containing kimchi. J Biotechnol 2007;131:300-8.

[69] Kim DH, Kim SH, Ko IB, Lee CH, Shin HS. Start-up strategy for continuous fermentative hydrogen production: early switchover from batch to continuous operation. Int J Hydrog Energy 2008:331532-41.

[70] Akutsu Y, Li YY, Tandukar M, Kubota K, Harada H. Effects of seed sludge on fermentative characteristics and microbial community structures in thermophilic hydrogen fermentation of starch. Int J Hydrog Energy 2008;33:6541-8.

[71] Chang JS, Lee KS, Lin PJ. Biohydrogen production with fixed-bed bioreactors. Int J Hydrog Energy 2002;27:1167-74. 
[72] Gadow SI, Jiang H, Hojo T, Li YY. Cellulosic hydrogen production and microbial community characterization in hyper-thermophilic continuous bioreactor. Int J Hydrog Energy 2013;38:7259-67.

[73] Akutsu Y, Lee DY, Chi YZ, Li YY, Harada H, Yu HQ. Thermophilic fermentative hydrogen production from starch-wastewater with bio-granules. Int J Hydrog Energy 2009;34:5061-71.

[74] Antonopoulou G, Gavala HN, Skiadas IV, Lyberatos G. Influence of pH on fermentative hydrogen production from sweet sorghum extract. Int J Hydrog Energy 2010;35:1921-8.

[75] Azbar N, Dokgöz FTC, Keskin T, Korkmaz KS, Syed HM. Continuous fermentative hydrogen production from cheese whey wastewater under thermophilic anaerobic conditions. Int J Hydrog Energy 2009;34:7441-7.

[76] Hussy I, Hawkes FR, Dinsdale R, Hawkes DL. Continuous fermentative hydrogen production from sucrose and sugarbeet. Int J Hydrog Energy 2005;30: 471-83
[77] Jung KW, Kim DH, Kim SH, Shin HS. Continuous fermentative hydrogen production from coffee drink manufacturing wastewater by applying UASB reactor. Int J Hydrog Energy 2010;35:13370-8.

[78] Jung KW, Kim DH, Kim SH, Shin HS. Continuous fermentative hydrogen and methane production from Laminaria japonica using a two-stage fermentation system with recycling of methane fermented effluent. Int J Hydrog Energy 2012;37:15648-57.

[79] Yang P, Zhang R, McGarvey JA, Benemann JR. Biohydrogen production from cheese processing wastewater by anaerobic fermentation using mixed microbial communities. Int J Hydrog Energy 2007;32:4761-71. 